\title{
A Survey Study on Parasite Presence of Edible Wild Terrestrial Snails (Helix pomatia L.) in Northern Cyprus
}

\author{
Fatma K. Yildirim (Corresponding author) \\ Near East University Faculty of Veterinary Medicine \\ Food Hygiene and Technology Department, Nicosia, Cyprus \\ E-mail: fatma.kaya@neu.edu.tr \\ Beyza H. Ulusoy \\ Near East University Faculty of Veterinary Medicine \\ Food Hygiene and Technology Department, Nicosia, Cyprus \\ E-mail: beyza.ulusoy@neu.edu.tr \\ Semahat Z. Erdogmus \\ Near East University Faculty of Veterinary Medicine \\ Parasitology Department, Nicosia, Cyprus \\ E-mail: zerrin.erdogmus@neu.edu.tr \\ Canan Hecer \\ Near East University Faculty of Veterinary Medicine \\ Food Hygiene and Technology Department, Nicosia, Cyprus \\ E-mail: canan.hecer@neu.edu.tr
}

\begin{abstract}
Edible terrestrial snails are important protein source for human nutrition with low fat. On the other hand, it is known that snails are hosts for some of the parasites which may pose serious health hazards for humans. That's why the reason it is important to put those edible molluscs under spotlight in terms of food safety. Depending our scientific report survey, no studies have been carried out related to terrestrial snails subjected to human consumption in North Cyprus. In this study, it was aimed to determine the parasite presence of snails consumed as food in Northern Cyprus. The snail samples $(n=250)$, were collected from their natural wild habitat at Buyukkonuk region in rainy season at April-May 2019. The samples were dissected and internal organs were examined for the presence of parasites. As a result of the study, no parasites were observed in a total of 250 snail samples. In order to understand the public health risk regarding snail consumption, more studies should be planned on bacteriological, parasitological and virology investigations in Northern Cyprus.
\end{abstract}

Keywords: Roman snail, food, public health, Cypriot cuisine

DOI: $10.7176 / \mathrm{JSTR} / 6-09-02$

\section{Introduction}

Snails are member of the phylum Mollusca and class Gastropoda. The genus, includes about 40 species in Europe, the Mediterranean, North Africa and some parts of Asia. Helix species (e.g. H. aspersa Müller, H. pomatia L., H. lucorum L.) are the one which are consumed by humans as food [1]. Roman snail (Helix pomatia L.) has a long history of being used as food. It is widely consumed in countries such as France, Belgium, Germany and Italy. Nutritional value of snail meat has been reported to contain high protein $(13,4-16,33 \%)$ and low-fat content $(1,08-1,40 \%)$ and is rich in essential fatty acids such as linolenic, linoleic acids [2, 3]. In addition, snail meat is rich in copper (29.3mg / 100g) and iron (14.0mg $/ 100 \mathrm{~g}$ ) and has been reported to contain high amounts of zinc in comparison to other meat species. It is also stated that snail meat is an" important source of selenium [4]. The ever-increasing demand has made it a valuable food product and added to the luxury product group such as caviar, foie gras, truffles [5]. As Omole et. al. [6] mentioned, snail consumption rate is rising against red meat. Studies have shown that Helix pomatia L. is more preferred due to its high protein, amino acid and mineral salt content compared to other species of terrestrial snails [7-9].

11 | P a g e

www.iiste.org 
More than 300 million people suffer from a range of diseases caused by gastropod-borne helminths, predominantly flatworms and roundworms, whose life cycles are passed through a gastropod. Molluscs have been long known to serve as ideal hosts for several parasites, including nematodes and trematodes [10]. Snails are found and live on soil either scavenging for food or for purposes of reproduction; thus snails could get infected with parasites. So contaminated snail consumption could be one route to human infection particularly when eaten raw or undercooked [11]. Angiostrongylus cantonensis is a zoonotic parasite that causes eosinophilic meningitis in humans after they ingest infective larvae in terrestrial snails [12]. Fasciola hepatica and Fasciola gigantica have also ability to infect snails and have a cosmopolitan distribution [13]. As Dorny et al. [12] rewied in their manuscript, the most important mollusc borne protozoa are Giardia spp., Cryptosporidium spp. and helmints are Angiostrongylus cantonensis Echinostoma spp. It is reported that, Brachylaima cribbi is a trematode which infects Helix aspersa Müller and other Helix species in Australia [14]. Sufficient heat treatment, freezing, conventional salting, fumigation, fermenting and marinating methods can be considered as methods used to neutralize parasites in foods. The main factor leading to human infection is the consumption as raw or insufficient heat treatment $[5,12]$.

In this study, we observed that snail species, which are the subject of Cypriot food and drink culture, are mostly roman snails and is more concentrated in the Karpas region of the country. The Cypriot people named these edible snails as garavolli which derives from the Greek word garaolos [15]. In Turkish Cypriot cuisine garavolli is mostly consumed in the form of boiled, kebab (grilled), and pickles [16, 17]. The way of cooking the snails in Cypriot cuisine culture may provide survival of parasites in these hosts especially if the heat treatment is insufficient. When the garavolli dish is prepared as ragout (yahni) the snails were cooked with their shells and mixed with vegetables (such as onion and tomatoes) in a pan. During this process internal temperature of snail meat may be low due to the shells. Kirkan et al. [18] observed in their study that internal temperature of snail meat was $85{ }^{\circ} \mathrm{C}$ after boiling at $100{ }^{\circ} \mathrm{C}$ for 4 $\min$.

Depending our scientific report survey, no studies have been carried out related to terrestrial snails subjected to human consumption in North Cyprus. To date, we have not encountered one study indicating the parasitological quality of snail meat that consumed in within this region. The aim of this study was to evaluate the presence of parasites in mostly consumed edible terrestrial snail genus Helix pomatia L. in terms of public health, in Northern Cyprus and to contribute to the database.

\section{Material and Method}

\subsection{Surveyed area}

Snail samples were collected from the village named as Büyükkonuk which is formerly known as Komi Kebir $\left(35^{\circ} 24^{\prime} 36^{\prime \prime} \mathrm{N} 33^{\circ} 59^{\prime} 49^{\prime \prime} \mathrm{E}\right)$. This village with a population of about 800, is located on the foothills of the Five Fingered (Beş Parmak) Mountain Range as it stretches into the 'panhandle' shaped peninsula which is called Karpas [19]. It is located on 33 kilometres north of Famagusta and at an altitude of 90 metres. İskele is neighbouring to the south-west and Mehmetcik to the north-east (Fig 1). Büyükkonuk is the first, Ministry confirmed, eco-touristic village in North Cyprus [19]. On the other hand, Büyükkonuk province and depending on our observations on field, the mostly consumed edible terrestrial snails (Helix pomatia L.) are concentrated in this area.

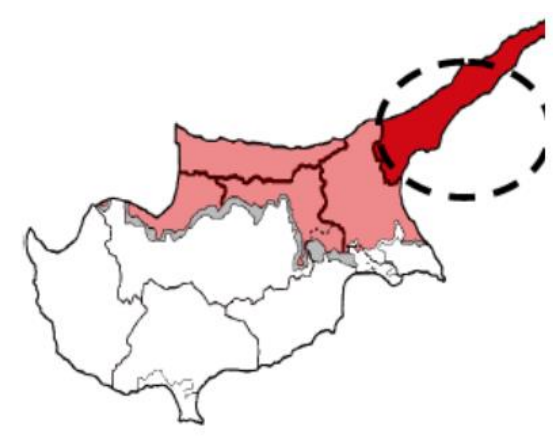

Figure 1: Karpaz peninsula and Büyükkonuk (Komi Kebir)

\subsection{Sample collection}

The mature, sizable snails were collected by handpicking from their natural habitat (farmland, bushes and around of houses) on soil, on leaves, on the trunk of trees and from the walls of the houses in the study area. A total of 250 samples were collected and studied for our research. The collection took place

12 | P a g e

www.iiste.org 
in April and May (April 2019 - May 2019) in the rainy season for once a week. Each snail was kept separately in sterile bag until they were brought to laboratory.

\subsection{Snail identification and dissection}

Snails were identified according to their shape, size, markings, colour. According to the identification, the snail species with a large shell that can reach $30-50 \mathrm{~mm}$ in height and $32-50 \mathrm{~mm}$ in width are confirmed to be Helix pomatia L. (Figure 2). This snail has a thin shell, pale spiral lines, a brownish colour [20].

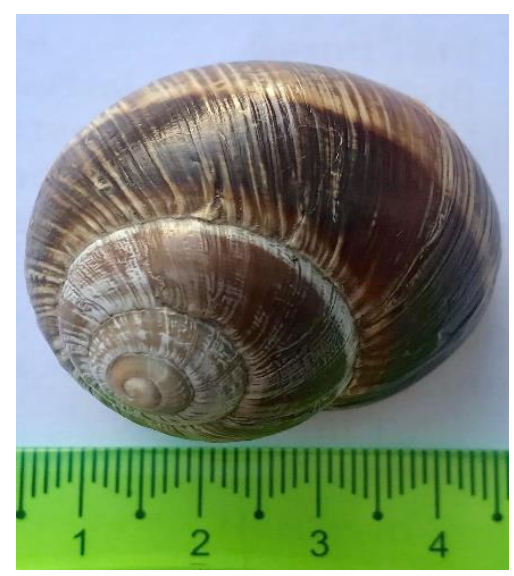

Figure 2: The typical shell of Helix pomatia L.

The snails were individually anaesthetized with ethereal cotton placed in sterile plastic sample cup and then separated from the shell with scissors and forceps [21, 22]. Food Hygiene and Technology and Parasitology Laboratory of the Faculty of Veterinary Medicine, Near East University.

\subsection{Parasitological investigation}

Internal organs and hepatopancreas were collected in petri dishes containing saline. The tissues in the petri dish were cut into small pieces with the help of forceps and needles. The parasites were allowed to dissolve for a while. The stereo microscope (Kent Scientific Corporation) was examined for parasitic larvae. In addition, samples taken from the physiological water between the slide and coverslip by pasteur pipette were examined under a microscope (Leica 8040124363VR0055).

\section{Results and Discussion}

No parasites were detected in 250 snail samples collected from Büyükkonuk region. Further studies should be planned with higher number of samples and within a wider area.

Parasitic foodborne diseases have become more widespread with international travels and increased human population and fast food habits. Studies have shown that they are detected more because of better diagnostic tools and improved technology [12]. Snail-induced parasitic diseases (SBPDs) are major parasitic diseases that continue to be a major public health problem worldwide, particularly in poor countries where snails are consumed as human food [23]. Snail consumption may cause human infection, especially when eaten raw or undercooked $[24,11]$. Therefore, determination of parasites in snails is of great importance. Many studies conducted so far, have mentioned the existence of parasites that cause serious diseases by passing from snails to humans and other animals [25]. In a study conducted in Galicia in Spain, in Helix aspersa maxima snails, Tetrahymena rostrata, Tetrahymena limacis, Tetratrichomonas limacis, Alloionema appendiculatum, Riccardoella limacum, Cryptobia helicogenae, Nemhelix baker and Brachylaima aspersae parasites are detected [26]. In another study, 20 snails were investigated in terms of endohelmint in Elazig region of Keban region. As a result of this examination 20\% (4 parasites) of snail samples observed to carry Paragonimus sp. (Trematoda; Digenea) and 30\% (6 parasites) of them carried Protostrogylus sp. (Nematoda; Metastrongyloidea) [25]. In the study carried out in Biwa Lake, 28 digenetic trematod taxa were detected in 19209 snails consisting of 10 morphological species [27]. In a study in Ghana, 150 snails (75 Achatina achatina and 75 Achatina fulica) were examined bacteriologically, parasitologically and mycologically. Giardia spp, Balantidium coli and trophozoites, unidentified parasite cysts were isolated. The results of the study indicate that snails can carry risks for public health [28]. Safer [29] detected Strongyloides stercoralis in snails. According to this study, 
Strongyloides stercoralis can easily penetrate into the snail and infect internal organs easily, as well as being the main parasites of terrestrial snails. Libero et al. [30] examined Achatina fulica snails $(\mathrm{n}=452)$ in terms of parasites presence. At the end of this study, Schistosoma mansoni, Trichuris spp., Hymenolepis spp., Strongyloides spp. detected in snail samples.

\section{Conclusion}

Snails are considered as a pollutant vector because they live in soil and are fed with plants with potential microbiological risks. Because of that, the edible snails may carry many parasitic and bacterial hazards and the evaluation of hygienic aspects is of great importance. In our study, Helix pomatia L. snail samples in Büyükkonuk region showed a good hygiene status in terms of parasites. In order to preserve the consumption volume of this product, which is becoming more and more popular in the food market, control measures and necessary legislative arrangements are needed. In particular, food enterprises should also pay attention throughout the production chain and distribution to prevent parasitic contamination and also other microbiological parameters that related with public health. It should be aimed to prevent foodborne diseases by taking care of the quality of the raw materials and production practices with hygienic care. Care should be taken to wash fresh snails, which are at risk for human health, before being consumed and to cook with sufficient heat treatment. In order to understand the public health risk regarding snail consumption, more studies should be planned on bacteriological, parasitological and virology investigations in Northern Cyprus.

\section{References}

1. Cicero, A., Giangrosso, G., Cammilleri, G., Macaluso, A., Currò, V., Galuppo, L., ... \& Ferrantelli, V. (2015). Microbiological and chemical analysis of land snails commercialised in Sicily. Iranian Journal of Fuzzy Systems, 4(2)

2. Olgunoglu, I.A., Olgunoglu, M.P. (2009). Preparation of frozen buttered snail (Helix lucorum Linnaeus, 1758) meat and analyses of food labels. Research Journal of Biological Sciences, 2(1), 35-39

3. Göçer, M., Olgunoğlu, İ.A. (2018). Comparison of Fatty Acid Profile of Edible Tissues of Wild Terrestrial Snail (Helix lucorum L. 1758) Collected in Two Province (Adana and Sinop). Turkish Journal of Agriculture - Food Science and Technology, 6(7), 877-880

4. Toader-Williams, A., Golubkina, N. (2009). Investigation upon the edible snail's potential as source of selenium for human health and nutrition observing its food chemical contaminant risk factor with heavy metals. Bulletin of University of Agricultural Sciences and Veterinary Medicine Cluj-Napoca, 66(2), 495-499

5. Arvanitoyannis, I.S., Varzakas, T.H. (2009). Application of failure mode and effect analysis (FMEA) and cause and effect analysis in conjunction with ISO 22000 to a snail (Helix aspersa) processing plant; A case study. Critical Reviews in Food Science, 49(7), 607-625

6. Omole, A.J., Oluokun, J.A., Fapounda, J.B., Osayemi, J. (2006). The effects of different stocking rates on growth and reproductive perfor- mance of breeding snail (Archachatina marginata) under intensive system of production in the humid tropics. Global Veterinaria, 1(1), 33-35

7. Yııdırım, M.Z., Kebapçı, Ü., Gümüş, B.A. (2004). Edible snails (terrestrial) of Turkey. Turkish Journal of Zoology, 28(4), 329-335

8. Andreev, N. (2006). Assessment of the status of wild populations of land snail (escargot) Helix pomatia L. in Moldova: the effect of exploitation. Biodiversity and Conservation, 15(9), 2957

9. Temelli, S., Dokuzlu, C., Sen, MKC. (2006). Determination of microbiological contamination sources during frozen snail meat processing stages. Food Control, 17(1), 22-29 
10. Giannelli, A., Cantacessi, C., Colella, V., Dantas-Torres, F., Otranto, D. (2016). Gastropod-borne helminths: a look at the snail-parasite interplay. Trends in Parasitology, 32(3), 255-264

11. Igbinosa, I.B., Isaac, C., Adamu, H.O., Adeleke, G. (2016). Parasites of edible land snails in Edo State, Nigeria. Helminthologia, 53(4), 331-335

12. Dorny, P., Praet, N., Deckers, N., Gabriël, S. (2009). Emerging food-borne parasites. Veterinary Parasitology, 163(3), 196-206

13. Mas-Coma, S., Barques, M.D., Valero, M.A. (2005). Fascioliasis and other plant-borne trematode zoonoses. International Journal for Parasitology, 35, 1255-1278

14. Butcher, A.R., Grove, D.I. (2001). Description of the life-cycle stages of Brachylaima cribbi $n$. sp. (Digenea: Brachylaimidae) derived from eggs recovered from human faeces in Australia. Syst. International Journal for Parasitology, 49, 211-221

15. Gümüşatam, G. (2011). Kavram Alanları Açısından Kıbrıs Türklerince Hayvanlara Verilen Adlar. Diyalektolog Sosyal Araştırmalar Hakemli Dergisi, 3, 11-32

16. Ankut, Z. (2007). Kıbrıs Türk ve Rum Mutfağının Karşılaştırılması Üzerinde Bir Çalışma. K.K.T.C. Yakın Doğu Üniversitesi, Egitim Bilimleri Enstitüsü. Halk Bilimi Egitimi Ana Bilim Dall, Yüksek Lisans Tezi, Lefkoşa

17. Özgen, L. (2015). Food Culture in Cyprus Kythrea Village Within the Context of Cross-Cultural Interaction. DBHAD Uluslararasi Hakemli Beslenme Araştirmalari Dergisi, 4

18. Kirkan, Ş., Göksoy, E.Ö., Kaya, O. (2006). Detection of Listeria monocytogenes by using PCR in Helix pomatia. Turkish Journal of Veterinary \& Animal Sciences, 30(4), 375-380

19. Elinç, Z.K., Cengiz, A., Elinç, H., Şahin, İ. (2011). Ecotourism in Büyükkonuk, North Cyprus. Inönü Üniversitesi Sanat ve Tasarım Dergisi, 1(3)

20. https://idtools.org/id/mollusc/factsheet.php?name=Helix\%20spp. Access: 24.07.2019

21. Segun, A.O. (1973). Land snails (Dissection guides of common tropical animals). Ethiope Publications

22. Kerney, M.P., Cameron, R.A.D. (1979). A field guide to the land snails of Britain and North-West Europe, Collins, London. pg 228

23. Lu, X.T., Gu, Q.Y., Limpanont, Y., Song, L.G., Wu, Z.D., Okanurak, K., Lv, Z.Y. (2018). Snailborne parasitic diseases: an update on global epidemiological distribution, transmission interruption and control methods. Infectious Diseases of Poverty, 7(1), 28

24. Caron, Y., Martens, K., Lempereur, L., Saegerman, C., Losson, B. (2014). New insight in lymnaeid snails (Mollusca, Gastropoda) as intermediate hosts of Fasciola hepatica (Trematoda, Digenea) in Belgium and Luxembourg. Parasites \& Vectors, 7(1), 66

25. Sağlam, N., Gökhan, H.B. (2006). Elazıg, Keban Yöresinde Yaşayan Salyangoz (Helix lucorum Linnaeus, 1758)'da Endohelmintlerin Araştırılması. Journal Su Ürünleri Dergisi, 23(2)

26. Segade, P., Crespo, C., Garcia, N., Garcia-Estévez, J.M., Arias, C., Iglesias, R. (2011). Brachylaima aspersae n. sp. (Digenea: Brachylaimidae) infecting farmed snails in NW Spain: Morphology, life cycle, pathology, and implications for heliciculture. Veterinary Parasitology, 175(3-4), 273-286

27. Urabe, M. (2003). Trematode fauna of prosobranch snails of the genus Semisulcospira in Lake Biwa and the connected drainage system. Parasitology International, 52(1), 21-34

15 | P a g e

www.iiste.org 
28. Barimah, M.N.Y. (2013). Microbiological Quality of Edible Land Snails from Selected Markets in Ghana (Doctoral dissertation, University of Ghana).

29. Safer, D., Brenes, M., Dunipace, S., Schad, G. (2007). Urocanic acid is a major chemoattractant for the skin-penetrating parasitic nematode Strongyloides stercoralis. Proceedings of the National Academy of Sciences, 104(5), 1627-1630

30. Liboria, M., Morales, G., Carmen, S., Isbelia, S., Luz, A. (2010). First finding in Venezuela of Schistosoma mansoni eggs and other helminths of interest in public health found in faeces and mucous secretion of the mollusc Achatina fulica (Bowdich, 1822). Zootecnia Tropical, 28(3), 383-394 